\title{
Knowledge, perception and practices towards sickle cell disease: a community survey among adults in Lubaga division, Kampala Uganda
}

Sharifu K. Tusuubira ${ }^{1,2^{*}}$ (D) Ritah Nakayinga ${ }^{2}$, Bashir Mwambi ${ }^{2}$, John Odda ${ }^{2}$, Sylvia Kiconco ${ }^{2}$ and Alimah Komuhangi $i^{2}$

\begin{abstract}
Background: Worldwide, the burden of Sickle Cell disease (SCD) has not been amply addressed. In Africa, Uganda has the 5th highest burden, a situation aggravated by limited and inaccessible formal social support structures to aid patients and families cope better with the psychosocial burden of SCD. In addition, this has been coupled with stigmatization and discrimination of people living with sickle cell disease causing isolation from family and society.

Method: This cross sectional study therefore set out to determine the attitudes, perception and level of awareness towards Sickle Cell disease in Ugandan communities. The study used an interviewer administered questionnaires to collect the data.

Results: Out of 110 people sampled; $91.2 \%$ of the respondents had ever heard of SCD with the highest proportion $38.7 \%$ hearing of SCD from friends and family. Close to half of the respondents $48 \%$ knew that SCD is inherited, however a large proportion $44.2 \%$ did not know the cause of SCD. However, $68.7 \%$ of the respondents said they cannot marry a person with SCD.

Conclusion: The study results indicate that more effort needs to be done to promote sickle cell awareness in Uganda communities with emphasis on the inclusion of sickle cell in health education campaigns.
\end{abstract}

Keywords: Sickle cell awareness, Campaigns, KAP, Uganda

\section{Background}

Sickle Cell Disease (SCD) is the most common monogenic blood disorder worldwide. It is associated with progressive organ damage coupled with episodes of acute illness [1]. The episodes of acute illness result from the sticky and stiff red blood cells which clog tiny blood vessels. This often results into various conditions not limited to organ and tissue damage, anemia, increased risk of infection and painful episodes [2].

Worldwide, SCD contributes a significant burden that is not amply addressed [3]. It is estimated that 312,000 children will be born worldwide with SCD annually [4].

\footnotetext{
* Correspondence: stusuubira@ciu.ac.ug

${ }^{1}$ Uganda Sickle Cell Rescue Foundation, Plot 4/5 Hotel Close Wampewo Avenue, Clock Tower, P.O. Box 71887, Kampala, Uganda

${ }^{2}$ Clarke International University (formerly International Health Sciences

University), St. Barnabas Road, Kisugu- Namuwongo, P.O.Box 7782, Kampala, Uganda
}

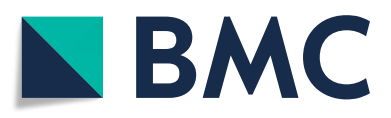

(C) The Author(s). 2018 Open Access This article is distributed under the terms of the Creative Commons Attribution 4.0 International License (http://creativecommons.org/licenses/by/4.0/), which permits unrestricted use, distribution, and

reproduction in any medium, provided you give appropriate credit to the original author(s) and the source, provide a link to the Creative Commons license, and indicate if changes were made. The Creative Commons Public Domain Dedication waiver (http://creativecommons.org/publicdomain/zero/1.0/) applies to the data made available in this article, unless otherwise stated.

With the greatest burden existing in Sub-Saharan Africa, where $75 \%$ of the world sickle cell disease occurs [5]. In Uganda estimates suggest that 15,000 babies are born each year with sickle cell disease [6]. WHO has indicated the need to improve disease prevention, awareness and early detection in Africa $[7,8]$.

As a result, the Uganda Sickle Cell Rescue Foundation has been actively championing sickle cell disease awareness and prevention since 2013. Following the Ndeezi et al. 2016 study, the Ministry of Health, Uganda has also made significant strides in addressing the sickle cell disease burden by introducing the newborn screening program in selected districts with the highest disease burden. This increased attention is geared to reducing sickle cell related mortality while increasing care and management outcomes. Sickle cell care and management outcomes are complicated by the complex interaction of 
SCD patients with the socio-ecological system [9-11]. The dilemma of the person living with sickle cell disease goes beyond grappling with the overwhelming health effects of the disease. The people are often stigmatized and discriminated; this often forces families to hide their sick [12].This survey therefore set out to determine the prevalence, attitudes, perception and knowledge towards Sickle Cell disease in Ugandan adults. This information is crucial in drawing attention to potential areas for intervention and improvement to foster better outcomes in Sickle cell prevention, awareness and management.

\section{Methods}

\section{Study area}

The study was carried out in Lusazze village a peri urban suburb located in Lubaga division, central region of Uganda.

\section{Study design}

The study was a cross-sectional survey. Data were collected between October and September 2016 using a structured questionnaire. The Participants completed a demographic questionnaire which contained information about age, gender, marital status, number of children etc. The other questionnaires were related to knowledge, attitudes and perceptions towards sickle cell disease. Sickle cell screening was also done for participants who provided additional consent. Sickle cell screening was carried out using the solubility test [Biolab, India] [13].

\section{Sample size and sampling technique}

The survey considered a sample size of 110 participants which was obtained using the formula by Kish and Leslie (1965) for cross-sectional studies. [14]. A 95\% level of confidence, $50 \%$ proportion was estimated and a $5 \%$ level of precision were used in the sample size calculation. Convenient sampling was used to select the participants such that all individuals who met the inclusion criteria were included in the survey. Eligible participants were community members who had lived in Lusazze for a period not less than six months. These were interviewed as they came to take part in a sickle cell community outreach.

\section{Sickle cell community outreach}

Uganda Sickle Cell Rescue Foundation carries out awareness activities aimed at having communities of sickle cell disease and its social connotations. Before the outreach announcements are made to inform the community about the event. As part of the event, sickle cell information is shared particularly what sickle cell is, how it is caused and how participants can prevent it. In addition, sickle cell screening is offered so as to enable participants know their genotype.

\section{Results}

Characteristics of respondents

From Table 1 below, close to two thirds (61.8\%) of the respondents are female and in the age group between 19 and 28 years. Slightly more than half $(52.9 \%)$ of the respondents were not in union (single). The highest proportion of respondents (62.7\%) had biological children. More than half $(56.9 \%)$ of the respondents knew their SCD status.

\section{Knowledge of respondents on sickle cell disease}

From Table 2 below, the vast majority (91.2\%) of the respondents had ever heard of SCD with the highest proportion $(38.7 \%)$ of the respondents hearing of SCD from friends and family. Close to half of the respondents (48\%) knew that SCD is inherited, however a large proportion (44.2\%) did not know the cause of SCD. More than half of the respondents knew some signs and symptoms of SCD. Unfortunately, half of the respondents $(50 \%)$ did not know how SCD is diagnosed. The highest proportion (45.1\%) of the respondents did not know the chance of having a healthy baby when all the parents have SCD. Majority (76.5\%) of the respondents noted that conventional medicine was the ideal treatment for SCD.

\section{Respondents' practice and perception on SCD}

From Table 3 below, the vast majority (83.4\%) had never tested for SCD, most (90. 2\%) of the respondents did not know their partner's genotype. Most of the respondents (74.3\%) reported that they wanted to know their SCD

Table 1 Characteristics of respondents

\begin{tabular}{lll}
\hline Variable & Frequency $(N=102)$ & Percentage (\%) \\
\hline Sex & 39 & 38.2 \\
Male & 63 & 61.8 \\
Female & & \\
Age group (years) & 13 & 12.7 \\
$<18$ & 63 & 61.8 \\
19-28 & 20 & 19.6 \\
$29-38$ & 6 & 5.9 \\
$>38$ & & \\
Marital status & 48 & 47.1 \\
In union & 54 & 52.9 \\
Not in union & & \\
Have biological children & & 62.7 \\
Yes & 64 & 37.3 \\
No & 38 & 56.9 \\
Know your SCD status & & 43.1 \\
Yes & 58 & \\
No & 44 & \\
\hline
\end{tabular}


Table 2 Knowledge on Sickle cell disease

\begin{tabular}{|c|c|c|}
\hline Variable & $\begin{array}{l}\text { Frequency } \\
(N=102)\end{array}$ & $\begin{array}{l}\text { Percentage } \\
(\%)\end{array}$ \\
\hline \multicolumn{3}{|l|}{ Heard of sickle cell disease } \\
\hline Yes & 93 & 91.2 \\
\hline No & 09 & 8.8 \\
\hline \multicolumn{3}{|l|}{ Source of information $(N=93)$} \\
\hline $\begin{array}{l}\text { Health professional/ community } \\
\text { meetings }\end{array}$ & 11 & 11.3 \\
\hline TV/ radio & 24 & 25.8 \\
\hline Internet & 22 & 24.2 \\
\hline Friends /family & 36 & 38.7 \\
\hline \multicolumn{3}{|l|}{ Causes of SCD } \\
\hline Acquired & 8 & 7.8 \\
\hline Inherited & 49 & 48.0 \\
\hline Don't know & 45 & 44.2 \\
\hline \multicolumn{3}{|l|}{ Signs \& symptoms } \\
\hline Frequent illness & 53 & 52.0 \\
\hline Yellow eyes & 7 & 6.9 \\
\hline Don't know & 42 & 41.1 \\
\hline \multicolumn{3}{|l|}{ How SCD is diagnosed } \\
\hline Blood test & 45 & 44.1 \\
\hline Urine test & 6 & 5.9 \\
\hline Don't know & 51 & 50.0 \\
\hline \multicolumn{3}{|l|}{ SCD prevention } \\
\hline Genetic counseling & 22 & 21.6 \\
\hline Don't know & 39 & 38.2 \\
\hline Testing before marriage & 41 & 40.2 \\
\hline \multicolumn{3}{|l|}{$\begin{array}{l}\text { Chance of getting a healthy baby when } \\
\text { all the parents have SCD }\end{array}$} \\
\hline None of the children & 5 & 4.9 \\
\hline All the children & 37 & 36.3 \\
\hline Half chance of the children & 11 & 10.8 \\
\hline Quarter chance baby will be normal & 3 & 2.9 \\
\hline Don't know & 46 & 45.1 \\
\hline \multicolumn{3}{|l|}{ Medication for people with SCD } \\
\hline Herbal medicine & 7 & 6.8 \\
\hline Conventional medicine & 78 & 76.5 \\
\hline Prayers & 6 & 5.9 \\
\hline Don't know & 11 & 10.8 \\
\hline
\end{tabular}

status as their reason to test and the highest proportion $(60.8 \%)$ noted that knowing their SCD status influenced or can influence their decision to marry while more than two thirds $(68.7 \%$,) of the respondents cannot marry a person with SCD. When asked whether people with SCD can work, more than two thirds $70 \%$ of the respondents reported that they can work while out of those
Table 3 Practice and Perception of SCD

\begin{tabular}{|c|c|c|}
\hline Variable & Frequency $(N=102)$ & Percentage (\%) \\
\hline \multicolumn{3}{|c|}{ Have you ever tested for SCD } \\
\hline Yes & 20 & 19.6 \\
\hline No & 82 & 83.4 \\
\hline \multicolumn{3}{|c|}{ Do you know your partner's genotype } \\
\hline Yes & 10 & 9.8 \\
\hline No & 92 & 90.2 \\
\hline \multicolumn{3}{|l|}{ Reason to test $(n=74)$} \\
\hline Curiosity & 19 & 25.7 \\
\hline To know SCD status & 55 & 74.3 \\
\hline \multicolumn{3}{|c|}{ Did/ Would knowing your status influence your decision to marry } \\
\hline Yes & 62 & 60.8 \\
\hline No & 40 & 39.2 \\
\hline \multicolumn{3}{|c|}{ Would you marry someone with SCD } \\
\hline Yes & 32 & 31.7 \\
\hline No & 70 & 68.3 \\
\hline \multicolumn{3}{|c|}{ Can someone with SCD work } \\
\hline Yes & 70 & 68.3 \\
\hline No & 32 & 31.7 \\
\hline \multicolumn{3}{|c|}{ If No, why shouldn't they work $(n=32)$} \\
\hline They are very weak & 16 & 50.0 \\
\hline They fall ill very often & 16 & 50.0 \\
\hline
\end{tabular}

who reported that they cannot work; half reported that being very weak is the reason as to why they shouldn't work while the other $50 \%$ reported that they are often ill so they do not have to work.

\section{Discussion}

This survey presents one of the first SCD community based findings in Lusaze, a semi-urban area in Lubaga division, central region of Uganda. Most SCD campaigns in Uganda generally focus on creating awareness without collecting baseline data.

This survey targeted female and male adults. This campaign attracted a lower proportion of the males. This may be due the fact that most men were away for work or it may also be due to men's negative attitude as highlighted by Francis et al. 2008 [15] . The study results are similar to Musoke et al. 2014 who also highlighted that more women utilize health facilities/ services in Wakiso District [16]. This may continue to underscore community campaigns since men may be the decision makers in most Ugandan homes.

Most of the participants have heard of SCD which may imply that they know of its existence. However, the fact that only a small proportion obtained such information from a health professional or community meeting may suggest that there is limited effort in health care 
settings/system to inform the public of SCD. Besides having heard of the disease, a relatively lower proportion had knowledge on the causes, signs and symptoms and prevention and this indicates a much larger problem which may hinder control strategies. Orish et al. 2014 found out that in Ghana schools ranked highest as sources of sickle cell disease knowledge while families ranked highest in our study [17]. Families are often associated with stigma and discrimination coupled with myths / beliefs about sickle cell disease. One participant said 'my parents always cautioned us from marrying from a certain family because they always heard somebody hospitalized'. Families have sometimes been identified as precipitators of stigma and discrimination [18]. The results indicate a percentage of people who consider prayer and herbal medicine as a form of therapy for sickle cell disease yet this was a peri urban locality. This is in contrast to another study where rural Ugandans considered prayer as a form of treatment for chronic diseases [19]. This strengthens the need to promote more health education of sickle cell disease and other chronic illness.

Of note is that a substantial proportion of the participants indicated that they knew their status. When we asked them whether they had tested a greatest proportion had not and indeed the largest proportion had never been screened for SCD. This is because most of them associated sickle cell status with frequent illness which they were free from. This indicates a hefty gap in screening services, yet it may clearly influence family decisions and subsequent control of the disease in the population. Since majority of the participants did not know their partners' genotype, it may imply that SCD screening before or after marriage is not prioritized yet it may also influence personal or family decisions.

Regarding perception, SCD individuals may be stigmatized and discriminated against since most participants seem to perceive the disease negatively regarding marriage and work. This is similar to what other researchers have found out that individuals with SCD often report SCD related stigma [20, 21].

The study limitations include the small sample size from a single area interviewed over a limited period of time. The small sample size affects our ability to generalize the findings. We recommend future research to interview a larger sample size to be able to validate the findings of this study. The study results could also be affected by the recruitment criteria where participants were selected at the sickle cell community campaign. This could be due to their interest or lack of knowledge about sickle cell disease. The sampling approach utilized is prone to bias, given that this was a community event and the participants were largely self-selected.

\section{Conclusion}

The results show that the respondents have heard of sickle cell mostly from friends and family. Close to half of the respondents knew that SCD is inherited, however a large proportion did not know the cause of SCD. However, more than two thirds of the respondents said they cannot marry a person with SCD.

\section{Recommendations}

There is need for the formulation of strategies to encourage male involvement in SCD campaigns. It is essential for the inclusion of SCD in existing health education programs both at the community and health center settings/levels. The study results indicate that more effort needs to be done to promote sickle cell awareness in Uganda communities.

\section{Abbreviation \\ SCD: Sickle Cell Disease}

\section{Acknowledgements}

The authors want to thank the Vice Chancellor of Clarke International University (formerly International Health Sciences University) Dr. Rose Clarke Nanyonga for the support. They also want to thank Sam Sendiwala, Hamida Nakintu, Tracy Nagawa and volunteers like Christopher Katende of Lusazze for the contribution. They also extend their utmost thanks to Dr. Bulaimu Muwanga Kibirige, Mr. Erostus Nsubuga, Dr. Sikander Lalani, Dr. Lukiah Mulumba, Dr. Kaggwa Lawrence, Stuart Mwesigwa, Hajj. Haruna Kalule Kibirige and Sis Drolence Namirembe for the support.

Availability of data and materials

The authors confirm that the data and materials from this study are available.

Authors' contributions

ST and RN drafted the manuscript. ST, RN, BM, SK and AK participated in the design of the study and data collection. JO participated in the data collection. All authors read and commented on manuscript drafts. All authors approved the final draft. All authors read and approved the final manuscript.

\section{Ethics approval and consent to participate}

The ethics and research committee of Clarke International University (formerly International Health Sciences University) approved the study procedures. All participants provided informed written consent for participation after a discussion with a member of the study team.

\section{Competing interests}

The authors declare that they have no competing interests where financial or what so ever.

\section{Publisher's Note}

Springer Nature remains neutral with regard to jurisdictional claims in published maps and institutional affiliations.

Received: 26 October 2017 Accepted: 20 April 2018

Published online: 27 April 2018

References

1. Weatherall D, Hofman K, Rodgers G, Ruffi NJ, Hrynkow S. A case for developing north-south partnerships for research in sickle cell disease. Blood. 2005;105:921-3.

2. Centers for Disease Control and Protection (2015) What is sickle cell disease? Available at: https:/www.nhlbi.nih.gov/health-topics/sickle-cell-disease. Accessed 20 July 2016.

3. Weatherall DJ. The inherited diseases of hemoglobin are an emerging global health burden. Blood. 2010;115:4331-6. 
4. Piel FB, Patil AP, Howes RE, et al. Global epidemiology of sickle haemoglobin in neonates: a contemporary geostatistical model-based map and population estimates. Lancet. 2013;381:142-51.

5. Piel FB, Hay SI, Gupta S, et al. Global burden of sickle cell anaemia in children under five, 2010-2050: modelling based on demographics, excess mortality, and interventions. PLoS Med. 2013;10:e1001484.

6. Ndeezi G, Kiyaga C, Hernandez AG, Munube D, Howard TA, Ssewanyana I, Nsungwa J, Kiguli S, Ndugwa CM, Ware RE, Jane R. Aceng burden of sickle cell trait and disease in the Uganda sickle surveillance study (US3): a crosssectional study lancet glob. Health. 2016;4:e195-200.

7. WHO. Sickle-cell anaemia. Report A59/9. Geneva: World Health Organization; 2006.

8. WHO. Sickle-cell disease: a strategy for the WHO African region. Report AFR RC60/8. Geneva: World Health Organization; 2010.

9. Haywood C Jr, Lanzkron S, Bediako S, et al. Perceived discrimination, patient trust, and adherence to medical recommendations among persons with sickle cell disease. J Gen Intern Med. 2014;29(12):1657-62. https://doi.org/10. 1007/s11606-014-2986-7

10. Zempsky WT, Loiselle KA, McKay K, Lee BH, Hagstrom JN, Schechter NL. Do children with sickle cell disease receive disparate care for pain in the emergency department? J Emerg Med. 2010;39(5):691-5. https://doi.org/10. 1016/j.jemermed.2009.06.003

11. Todd KH, Green C, Bonham VL Jr, Haywood C Jr, Ivy E. Sickle cell disease related pain: crisis and conflict. J Pain. 2006;7(7):453-8. https://doi.org/10 1016/j.jpain.2006.05.004

12. Uganda Sickle Cell Rescue Foundation .Sickle cell stigma Available at: http:// www.uscrfuganda.org/ Accessed in 02 Nov 2017.

13. Nalbandian RM, Nichols BM, Camp FR Jr, Lusher JM, Conte NF, Henry RL, Wolf PL. Dithionite tube test-a rapid, inexpensive technique for the detection of hemoglobin S and non-S sickling hemoglobin. Clin Chem. 1971;17(10):1028-32. PMID: 5095141

14. Kish L. Survey sampling. New York: John Wiley and Sons; 1965.

15. Bwambale F, Ssali S, Byaruhanga S, Kalyango J, Karamagi C. Voluntary HIV counselling and testing among men in rural western Uganda: implications for HIV prevention. BMC Public Health. 2008:8(1) https://doi.org/10.1186/ 1471-2458-8-263

16. Musoke D, Boynton P, Butler C, Musoke M. Health seeking behaviour and challenges in utilising health facilities in Wakiso district, Uganda. Afr Health Sci. 2015;14(4):1046. https://doi.org/10.4314/ahs.v14i4.36

17. Orish V, Onyeabor O, Sanyaolu A, Iriemenam N. Evaluating the knowledge of sickle cell disease and hemoglobin electrophoretic pattern among people living in Sekondi-Takoradi metropolis, Ghana. Journal Of Medicine In The Tropics. 2014;16(2):56. https://doi.org/10.4103/2276-7096.139047

18. Marsh V, Kamuya D, Molyneux S. 'All her children are born that way': gendered experiences of stigma in families affected by sickle cell disorder in rural Kenya. Ethnicity \& Health. 2011;16(4-5):343-59. https://doi.org/10.1080/ 13557858.2010 .541903

19. Nnko, S., Bukenya, D., Kavishe, B., Biraro, S., Peck, R., \& Kapiga, S. et al. (2015). Chronic diseases in north-West Tanzania and southern Uganda. Public perceptions of terminologies, Aetiologies, symptoms and preferred management. PLOS ONE, 10(11), e0142194. https://doi.org/10.1371/journal. pone.0142194

20. Adeyemo T, Ojewunmi O, Diaku-Akinwumi I, Ayinde O, Akanmu A. Health related quality of life and perception of stigmatisation in adolescents living with sickle cell disease in Nigeria: a cross sectional study. Pediatr Blood Cancer. 2015;62(7):1245-51.

21. Bediako S, Lanzkron S, Diener-West M, Onojobi G, Beach M, Haywood C. The measure of sickle cell stigma: initial findings from the improving patient outcomes through respect and trust study. J Health Psychol. 2014;21 (5):808-20.

\section{Ready to submit your research? Choose BMC and benefit from:}

- fast, convenient online submission

- thorough peer review by experienced researchers in your field

- rapid publication on acceptance

- support for research data, including large and complex data types

- gold Open Access which fosters wider collaboration and increased citations

- maximum visibility for your research: over $100 \mathrm{M}$ website views per year

At BMC, research is always in progress.

Learn more biomedcentral.com/submissions 